\title{
Sickle cell disease and malaria: decreased exposure and asplenia can modulate the risk from Plasmodium falciparum
}

Richard O. Mwaiswelo ${ }^{1,2^{*}}$, William Mawala ${ }^{3}$, Per O. Iversen ${ }^{3,4}$, Mariane de Montalembert ${ }^{5}$, Lucio Luzzatto ${ }^{3}$ and Julie Makani ${ }^{3}$

\begin{abstract}
Background: Patients with sickle cell disease (SCD), an inherited haemoglobinopathy, have increased risk of malaria, at least in part due to impaired splenic function. Infection with Plasmodium falciparum in SCD patients can trigger painful vaso-occlusive crisis, increase the severity of anaemia, and contribute to early childhood mortality.

Case presentation: A 17 year-old Tanzanian male with known SCD was admitted to Muhimbili National Hospital, a tertiary referral centre in Dar-es-Salaam, following an attack of malaria. From 2004 to 2007 the patient had lived in USA, and from 2010 to 2016 in France where, on account of hypersplenism and episodes of splenic sequestrations, in 2014 the spleen was removed. After appropriate clinical and laboratory assessment the patient was re-started on hydroxyurea; and anti-malarial-prophylaxis with proguanil was instituted. The patient has remained well and malariafree for the following 15 months.
\end{abstract}

Conclusion: SCD patients are highly vulnerable to malaria infection, and impaired splenic function is a feature of SCD patients, even in those who still anatomically have a spleen. This patient had a surgical splenectomy and, in addition, had probably lost some of the acquired malaria-immunity by having lived for several years in malaria-free areas. This patient is a compelling reminder that long-term anti-malarial prophylaxis should be offered to all patients with SCD who live in malaria-endemic areas.

Keywords: Chemoprophylaxis, Malaria, Sickle cell disease, Splenic dysfunction, Splenectomy

\section{Background}

Sickle cell disease (SCD) is an autosomal recessive disorder characterized by chronic haemolytic anaemia and painful vaso-occlusive crises. SCD is common in subSaharan Africa, with a birth prevalence that in some areas reaches $2 \%$ [1], and where it is therefore a true issue of public health importance. Without early diagnosis and appropriate care many children born with SCD do not survive beyond their fifth birthday [1,2].

*Correspondence: richiemwai@yahoo.com

${ }^{1}$ Department of Microbiology, Immunology and Parasitology, Hubert Kairuki Memorial University, Dar es Salaam, Tanzania

Full list of author information is available at the end of the article
SCD patients also experience increased susceptibility to severe infections, including malaria [3, 4]. This is particularly important because the geographic distribution of SCD parallels closely that of malaria, both disorders being frequent in the entire tropical belt of Africa, including Tanzania $[5,6]$. This parallel epidemiology is not a coincidence: rather, there is evidence that heterozygotes for the sickle gene (Hb genotype AS) are relatively protected against death due to malaria, probably through accelerated clearance by macrophages of Plasmodium falciparum-infected erythrocytes [7]. On the other hand, homozygous (Hb SS) SCD patients are at increased risk of dying from malaria $[3,4,7]$.

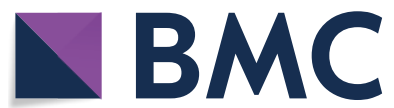

(c) The Author(s) 2020. This article is licensed under a Creative Commons Attribution 4.0 International License, which permits use, sharing, adaptation, distribution and reproduction in any medium or format, as long as you give appropriate credit to the original author(s) and the source, provide a link to the Creative Commons licence, and indicate if changes were made. The images or other third party material in this article are included in the article's Creative Commons licence, unless indicated otherwise in a credit line to the material. If material is not included in the article's Creative Commons licence and your intended use is not permitted by statutory regulation or exceeds the permitted use, you will need to obtain permission directly from the copyright holder. To view a copy of this licence, visit http://creativeco mmons.org/licenses/by/4.0/. The Creative Commons Public Domain Dedication waiver (http://creativecommons.org/publicdomain/ zero/1.0/) applies to the data made available in this article, unless otherwise stated in a credit line to the data. 
Splenic dysfunction may be responsible for increased susceptibility of SCD patients to malaria as well as to other infections $[8,9]$, as removal of abnormal erythrocytes and of intra-erythrocytic inclusions, including parasites, is one of the main functions of the spleen [10, 11]. Therefore, persons who are either splenectomized or who have impaired splenic function have increased susceptibility to malaria $[11,12]$. Immunity against malaria is complex, but in malaria-endemic areas some degree of immunity develops regularly. This may be weakened when recurrent exposure ceases, for example in a person who has moved to a malaria-free area [13].

In view of the higher malaria mortality rate in SCD patients, although it is questionable whether anti-malarial prophylaxis reduces the frequency of vaso-occlusive crises [14], this prophylaxis is recommended [15], but it is far from universally practiced in sub-Saharan countries $[1,5]$. This is true in Tanzania where anti-malarial chemoprophylaxis for SCD patient is an established policy that, however, is far from being regularly implemented.

This is a report of a patient with SCD who was asplenic, who had lived for several years in malaria-free environment and who, upon return to Tanzania, did not initially receive anti-malarial prophylaxis and suffered recurrently from malaria.

\section{Case presentation}

A 17 year-old Tanzanian male with known SCD came in May 2018 to the Sickle Cell Clinic at the Muhimbili National Hospital (MNH) in Dar-es-Salaam, Tanzania with a complaint of loss of appetite and nausea. The day before the patient had been discharged from a local hospital in Dar-es-Salaam where, having been admitted 5 days previously because of fever, nausea, loss of appetite, generalized body pain and weakness. Plasmodium falciparum malaria infection was diagnosed upon microscopic examination of blood slides. The patient was treated with artesunate injection followed by quinine tablets. A similar episode, with confirmed $P$. falciparum infection, had occurred some weeks earlier, when the patient had been treated with artemether-lumefantrine tablets.

The medical history showed that the patient had been diagnosed with SCD at the age of 2 years. At the age of 5 years when living in the USA, the patient was started on hydroxyurea. In 2007, he returned to Tanzania where, in 2008, he had an episode of malaria. In 2010, the patient moved to France where further investigations revealed that his SCD was sickle beta thalassaemia, and that he was also homozygous for alpha-thalassaemia. The beta thalassaemia mutation was identified as IVS1nt5G $>$ C . Deficiencies of coagulation factors VII and X were also detected. His steady-state $\mathrm{Hb}$ level was $10-11 \mathrm{~g} / \mathrm{dL}$; however, he required blood transfusion on 9 occasions because of recurrent exacerbations of anaemia, attributed to hypersplenism and recurrent splenic sequestration. Therefore in 2014 he had a laparoscopic splenectomy. The spleen weighed $428 \mathrm{~g}$ and histology showed marked congestion without haemosiderosis or other abnormalities.

In 2016, the patient returned to Tanzania where he now attends secondary school. In 2017 the patient was feeling so well that he stopped taking hydroxyurea, his steadystate haemoglobin being 9-10 $\mathrm{g} / \mathrm{dL}$, and his only medication was folic acid ( $5 \mathrm{mg} /$ day). However, recently he has had several bone pain crises.

On admission to MNH in May 2018 clinical examination did not reveal any specific findings. There was no severe pain and no evidence of infection. The patient's $\mathrm{Hb}$ was $7.3 \mathrm{~g} / \mathrm{dL}$ and a malaria test was negative. The patient continued on folic acid, hydroxyurea (500 $\mathrm{mg} /$ day) was re-introduced, and anti-malarial prophylaxis with proguanil $(100 \mathrm{mg} /$ day) was started. On monthly followup visits from June 2018 to September 2019 the patient has been generally well, except for occasional pain that responded to paracetamol, diclofenac or ibuprophen. Laboratory findings (Table 1 ) were stable.

A high performance liquid chromatography haemoglobin analysis confirmed in this patient the diagnosis of sickle beta thalassaemia (Table 2). The mother is an A/S heterozygote and the father is a beta-thalassaemia heterozygote. Surprisingly, the patient's sister, who reports having been generally well, was also found to have sickle beta thalassaemia.

\section{Discussion}

Malaria infection may be fatal in any person: however, the risk of fatality is influenced by several genetic and acquired factors. Among the former, SCD is one of the foremost: it increases greatly the mortality from malaria infection; probably in large part because the $P$. falciparum-induced destruction of both parasitized and non-parasitized erythrocytes will precipitate a severe exacerbation of the already existing chronic anaemia [16, 17]. This is in striking contrast to the well known significant protection enjoyed by haemoglobin $S$ heterozygotes (sickle cell trait) against P. falciparum malaria [7], and the triumph of good over evil: protection by the sickle gene against malaria [18]. In SCD malaria can also trigger painful vaso-occlusive crisis in SCD patients and it is among the leading causes of hospital admissions and mortality in endemic countries $[3,13]$.

As for acquired factors, partial immunity against malaria is usually acquired during the first 5 years of life, is dependent on the intensity of transmission and, therefore, on exposure frequency [19], and it tends to wane off with time if re-exposure does not occur $[19,20]$. 
Table 1 Laboratory findings obtained at hospital admission and outpatient follow-up visits

\begin{tabular}{|c|c|c|c|c|c|c|c|}
\hline Laboratory values & $\begin{array}{l}\text { Admission MNH } \\
\text { (may 2018) }\end{array}$ & $\begin{array}{l}\text { Visit } 1 \text { (june } \\
\text { 2018) }\end{array}$ & $\begin{array}{l}\text { Visit } 2 \text { (july } \\
\text { 2018) }\end{array}$ & $\begin{array}{l}\text { Visit } 3 \text { (aug } \\
\text { 2018) }\end{array}$ & $\begin{array}{l}\text { Visit } 4 \text { (sept } \\
\text { 2018) }\end{array}$ & $\begin{array}{l}\text { Visit } 5 \text { (march } \\
\text { 2019) }\end{array}$ & $\begin{array}{l}\text { Visit } 6 \\
\text { (sept } \\
\text { 2019) }\end{array}$ \\
\hline Haemoglobin (g/dL) & 7.3 & 8.5 & 10.8 & 10.4 & 10.5 & 10.8 & 11.2 \\
\hline Neutrophils $\left(\times 10^{9} / \mathrm{L}\right)$ & 2.8 & & & 6.1 & & & 4.3 \\
\hline Lymphocytes $\left(\times 10^{9} / \mathrm{L}\right)$ & 0.8 & & & 2.6 & & & 2.4 \\
\hline Monocytes $\left(\times 10^{9} / \mathrm{L}\right)$ & 0.3 & & & 0.5 & & & 0.7 \\
\hline Eosinophils $\left(\times 10^{9} / \mathrm{L}\right)$ & 0.03 & & & 0.1 & & & 0.1 \\
\hline Platelets $\left(\times 10^{9} / \mathrm{L}\right)$ & 384 & & & 344 & & & 265 \\
\hline Beta-glutamyl transferase $(U / L)$ & & & & 25.5 & & & \\
\hline Lactate dehydrogenase (U/L) & & & & 343 & & & \\
\hline Alanine aminotransferase $(\mathrm{U} / \mathrm{L})$ & & & & 19 & 20 & & \\
\hline Aspartate aminotransaminase (U/L) & & & & 26 & & & \\
\hline Bilirubin-total (mg/dL) & & & & 1.13 & 1.31 & & \\
\hline Creatinine (mg/dL) & & & & 0.73 & 0.81 & & \\
\hline
\end{tabular}

MNH Muhimbili National Hospital, $\mathrm{Hb}$ haemoglobin

Table 2 Blood profiles of patient and his family members

\begin{tabular}{|c|c|c|c|c|}
\hline Laboratory values & Patient & Mother & Father & Sister \\
\hline \multicolumn{5}{|l|}{ Blood values } \\
\hline $\mathrm{Hb}(\mathrm{g} / \mathrm{dL})$ & 10.4 & 10.0 & 11.0 & 9.4 \\
\hline $\mathrm{MCV}(\mathrm{fL})$ & 76.0 & 66.5 & 67.9 & 61.0 \\
\hline $\mathrm{MCHC}(\mathrm{g} / \mathrm{dL})$ & 34.7 & 31.6 & 31.9 & 33.6 \\
\hline Reticulocytes & 97.1 & NA & 72.6 & NA \\
\hline RDW (\%) & 40.0 & 42.2 & 36.7 & 39.9 \\
\hline Neutrophils $\left(\times 10^{9} / \mathrm{L}\right)$ & 3.7 & 3.0 & 4.6 & 4.8 \\
\hline Platelets $\left(\times 10^{9} / \mathrm{L}\right)$ & 294 & 342 & 221 & 126 \\
\hline Blood film & $\begin{array}{l}\text { Aniso-, poikilo-, elliptocytosis, very rare ISC } \\
\text { hypochromic cells. }\end{array}$ & Anisocytosis, target cells, & Anisocytosis, microcytosis & $\begin{array}{l}\text { Aniso-, poikilo-, } \\
\text { elliptocytosis, } \\
\text { target cells }\end{array}$ \\
\hline \multicolumn{5}{|c|}{ HPLC-data of Hb-subtypes (\%) } \\
\hline$A$ & 6.3 & 57.7 & 79.5 & 5.3 \\
\hline $\mathrm{A}_{2}$ & 6.8 & 2.7 & 4.1 & 5.6 \\
\hline $\mathrm{F}$ & 12.0 & 3.3 & 12.0 & 10.2 \\
\hline S & 73.0 & 34.5 & ND & 79.0 \\
\hline Other & ND & ND & 4 & ND \\
\hline Interpretation & Sickle beta-thalassaemia double heterozygote & AS heterozygote & Beta -thalassaemia heterozygote & $\begin{array}{l}\text { Sickle beta- } \\
\text { thalassaemia } \\
\text { double het- } \\
\text { erozygote }\end{array}$ \\
\hline
\end{tabular}

Values were measured in October 2019

$\mathrm{Hb}$ haemoglobin, $M C V$ mean cell volume, $M C H C$ mean cell $\mathrm{Hb}$ concentration, $R D W$ red cell distribution width, $H P L C$ high pressure liquid chromatography, NA not available, ND not determined

A previous study has found that immigrants of African origin who had lived in Sweden (a malaria-free country) for 15 years or more, once they returned to Africa had a risk of malaria infection and of severe malaria similar to that of non-African travellers [20]. In the defense against malaria a significant role is played by the spleen because, by virtue of its unique anatomy, it can retain parasitized erythrocytes (as well as non-parasitized, but otherwise abnormal erythrocytes); indeed, impaired splenic function reduces the clearance rate of malaria parasites from the circulation $[8,10,11]$. In SCD by early adulthood auto-splenectomy or functional asplenia is the rule rather 
than the exception: but, compared to homozygous sickle cell anaemia (SS), in sickle beta-thalassaemia the spleen is much more likely to persist and to remain enlarged even in adults. This may be associated with pooling of blood in the spleen that intermittently becomes greater (splenic sequestration) [21], whereby indications for splenectomy are more often compelling in sickle beta-thalassaemia compared to homozygous sickle cell anaemia.

In this patient each one of these factors seems to have conspired with the others: (i) The patient had sickle beta thalassemia, a well known form of SCD; (ii) he was asplenic; and (iii) after being born and having lived in Tanzania for the first 4 years of his life, he lived for a total of 8 years in malaria-free countries (USA and France), whereby whatever immunity he had previously developed may have faded. He had at least two documented episodes of malaria infection prior to his splenectomy, and at least two after splenectomy. In this patient, therefore, the spleen was removed for good clinical reasons, and the procedure was recommended only after a balanced judgment of pros and cons. One goal was to reduce substantially the rate of blood transfusion, and this was achieved. As for the implications of being asplenic, it must be accepted that living in a malaria-endemic region is an added risk.

Malaria episodes in this patient have been treated promptly: fortunately, because in a splenectomized SCD patient it might rapidly become life-threatening, a decision was made to institute anti-malarial chemoprophylaxis [15]. Officially recommended regimens in Tanzania include weekly mefloquine, daily atovaquone/proguanil, daily doxycycline, or weekly artemisinin-based combination therapy. None of these options is without side effects [22], in addition, the patient could not afford any of them. Hence, a widely used proguanil monotherapy drug was prescribed [23, 24]. Since Dar-es-Salaam is regarded as a low malaria transmission area, prophylaxis cannot be automatically credited with having prevented further episodes of malaria infection, but in the 18 months since starting proguanil the patient has had no malaria recurrence, no fever and no hospital admission. Since his last hospitalization in May 2018, his Hb level has risen significantly, which may be attributed to the combined effects of not having malaria infection and having resumed hydroxyurea therapy. Nonetheless, this case report illustrates what can happen (and probably often does happen) when anti-malarial chemoprophylaxis is not provided.

\section{Conclusion}

This patient was a living reminder that if SCD cannot be cured, then at least patients with SCD should be protected from falciparum malaria, an exogenous extra threat that is preventable.
Abbreviations

SCD: Sickle cell anaemia; Hb: Haemoglobin; HbSS: Homozygote for the sickle cell gene; HbAS: Heterozygote for the sickle cell gene; MNH: Muhimbili National Hospital.

\section{Acknowledgements}

The authors wish to extend their gratitude to the patient and his parents for granting the permission to report his history and findings. They also acknowledge the support from the staff of the Sickle Cell Center and of Muhimbili National Hospital.

\section{Authors' contributions}

ROM, WM, LL and JM designed the study. WM, JM, POI and MDM collected the patient's information. ROM, WM, POI, MDM, LL and JM analysed the data. $\mathrm{RM}, \mathrm{POI}$ and $\mathrm{LL}$ wrote the manuscript. All authors read and approved the final manuscript.

\section{Funding}

No funding was needed to publish this case report.

\section{Availability of data and materials}

The data collected during the current study are not publicly available due the privacy of the patient, but are available from the corresponding author on reasonable request.

\section{Ethics approval and consent to participate}

Consent to participate in the study and for the publication of the report was obtained from the patient.

\section{Consent for publication}

A copy of the written consent is available for review by the Editor-in-Chief of this journal.

\section{Competing interests}

The authors declare that they have no competing interests.

\section{Author details}

${ }^{1}$ Department of Microbiology, Immunology and Parasitology, Hubert Kairuki Memorial University, Dar es Salaam, Tanzania. ${ }^{2}$ Department of Parasitology and Medical Entomology, Muhimbili University of Health and Allied Sciences, Dar es Salaam, Tanzania. ${ }^{3}$ Department of Hematology and Blood Transfusion, Muhimbili University of Health and Allied Sciences, Dar es Salaam, Tanzania. ${ }^{4}$ Department of Haematology, Oslo University Hospital, Oslo, Norway. ${ }^{5}$ Department of General Pediatrics and Pediatric Infectious Diseases, NeckerEnfants malades Hospital, Assistance Publique-Hôpitaux de Paris, Université de Paris, Paris, France.

Received: 6 January 2020 Accepted: 28 March 2020

Published online: 25 April 2020

\section{References}

1. Wastnedge E, Patel S, Goh MY, Rudan I. The global burden of sickle cell disease in children under five years of age: a systematic review and metaanalysis. J Glob Health. 2018;8:021103.

2. Piel FB, Steinberg MH, Rees DC. Sickle cell disease. N Engl J Med. 2017;76:1561-73

3. McAuley CF, Webb C, Makani J, Macharia A, Uyoga S, Opi DH, et al. High mortality from Plasmodium falciparum malaria in children living with sickle cell anemia on the coast of Kenya. Blood. 2010;116:1663-8.

4. Makani J, Komba AN, Cox SE, Oruo J, Mwamtemi K, Kitundu J, et al. Malaria in patients with sickle cell anemia: burden, risk factors, and outcome at the outpatient clinic and during hospitalization. Blood. 2010;115:215-20.

5. Piel FB, Patil AP, Howes RE, Nyangiri OA, Gething PW, Dewi M, et al. Global epidemiology of sickle haemoglobin in neonates: a contemporary geostatistical model-based map and population estimates. Lancet. 2013;381 (9861):142-51. 
6. Wiebe A, Longbottom J, Gleave K, Shearer FM, Sinka ME, Massey NC, et al. Geographical distributions of African malaria vector sibling species and evidence for insecticide resistance. Malar J. 2017;16(1):85.

7. Luzzatto L. Sickle cell anaemia and malaria. Mediterr J Hematol Infect Dis. 2012;4(1):e2012065.

8. Tubman VN, Makani J. Turf wars: exploring splenomegaly in sickle cell disease in malaria-endemic regions. Br J Haematol. 2017;177(6):938-46.

9. Brousse $V$, Buffet $P$, Rees D. The spleen and sickle cell disease: the sick(led) spleen. Br J Haematol. 2014;166(2):165-76.

10. Chotivanich K, Udomsangpetch R, Mcgready R, Proux S, Newton P, Pukrittayakamee $S$, et al. Central role of the spleen in malaria parasite clearance. J Infect Dis. 2002;185(10):1538-41.

11. Demar M, Legrand E, Hommel D, Esterre P, Carme B. Plasmodium falciparum malaria in splenectomized patients: two case reports in French Guiana and a literature review. Am J Trop Med Hyg. 2004;71(3):290-3.

12. Davidson RN, Wall RA. Prevention and management of infections in patients without a spleen. Clin Microbiol Infect. 2001;7(12):657-60.

13. Menendez C, Fleming AF, Alonso PL. Malaria-related anaemia. Parasitol Today. 2000;16(11):469-76.

14. Frimpong A, Thiam LG, Arko-Boham B, Owusu EDA, Adjei GO. Safety and effectiveness of antimalarial therapy in sickle cell disease: a systematic review and network meta-analysis. BMC Infect Dis. 2018;18(1):650.

15. Oniyangi O, Omari AA. Malaria chemoprophylaxis in sickle cell disease. Cochrane Database Syst Rev. 2006;2006(4):CD003489.

16. White NJ. Anaemia and malaria. Malar J. 2018;17(1):371
17. Haldar K, Mohandas N. Malaria, erythrocytic infection, and anemia. Hematology Am Soc Hematol Educ Program. 2009;1:87-93.

18. Bunn HF. The triumph of good over evil: protection by the sickle gene against malaria. Blood. 2013;121(1):20-5.

19. Doolan DL, Dobano C, Baird JK. Acquired immunity to malaria. Clin Microbiol Rev. 2009;22(1):13-36.

20. Farnert A, Wyys K, Dashti S, Naucler P. Duration of residency in a nonendemic area and risk of severe malaria in African immigrants. Clin Microbiol Infect. 2015:21(5):494-501.

21. El Hoss S, Brousse V. Considering the spleen in sickle cell disease. Expert Rev Hematol. 2019;12(7):563-73.

22. Olaosebikan R, Ernest K, Bojang K, Mokuolu O, Rehman A, Affara M, et al. A randomized trial to compare the safety, tolerability, and effectiveness of 3 antimalarial regimens for the prevention of malaria in Nigerian patients with sickle cell disease. J Infect Dis. 2015;212(4):617-25.

23. Lalloo DG, Hill DR. Preventing malaria in travellers. BMJ. 2008;336(7657):1362-6

24. Schwartz E. Prophylaxis of malaria. Mediterr J Hematol Infect Dis. 2012;4(1):e2012045

\section{Publisher's Note}

Springer Nature remains neutral with regard to jurisdictional claims in published maps and institutional affiliations.
Ready to submit your research? Choose BMC and benefit from:

- fast, convenient online submission

- thorough peer review by experienced researchers in your field

- rapid publication on acceptance

- support for research data, including large and complex data types

- gold Open Access which fosters wider collaboration and increased citations

- maximum visibility for your research: over 100M website views per year

At BMC, research is always in progress.

Learn more biomedcentral.com/submissions 